\title{
HUBUNGAN KADAR HBA1C DENGAN REACTIVE OXYGEN SPECIES DALAM SERUM DARAH DAN GRADASI KATARAK PADA PASIEN KATARAK DENGAN DIABETES MELITUS
}

\author{
Nina Handayani* ${ }^{\star 凶}$, Pasenggo Trifena**, Wino Vrieda Vierlia*
}

\begin{abstract}
Abstrak
Katarak merupakan suatu kelainan yang ditandai dengan adanya kekeruhan pada lensa mata. Selain karena penuaan, faktor lain yang terlibat dalam pembentukan katarak adalah diabetes melitus. Kondisi hiperglikemia berasosiasi dengan stres oksidatif yang berperan dalam proses pembentukan katarak. Penelitian ini bertujuan untuk mengetahui hubungan antara kadar $\mathrm{HbA1C}$ dengan reactive oxygen species (ROS) dalam serum darah dan gradasi katarak pada pasien katarak dengan diabetes melitus. Penelitian ini bersifat observasional dengan rancangan cross-sectional dan teknik consecutive sampling dengan subjek sebanyak 44 orang yang terbagi menjadi 4 kelompok berdasarkan kadar $\mathrm{HbA1C}$ : (1). HbA1C normal, (2). $\mathrm{HbA1C}$ terkontrol baik $(<6,5 \%),(3)$. HbA1C terkontrol sedang $(6,5-7.9 \%)$, dan (4). HbA1C terkontrol buruk ( $\geq 8 \%$ ); dan 3 kelompok berdasarkan gradasi katarak. Hasil uji Kruskal-Wallis menunjukkan perbedaan signifikan $(p<0,05)$ rerata ROS pada masing-masing kelompok HbA1C. Kemudian dari hasil uji lanjut Mann -Whitney, tidak didapatkan perbedaan signifikan antara kelompok 1 dengan kelompok 2, 3, dan 4; terdapat perbedaan signifikan antara kelompok 2 dengan 3 dan 4; dan tidak didapatkan perbedaan signifikan antara kelompok 3 dan 4. Hasil uji korelasi Spearman menunjukkan terdapat hubungan negatif yang tidak signifikan antara kadar HbA1C dengan ROS pada kelompok $1(p=0,958, r=-0,016)$ dan pada kelompok $4(p=$ $0,163, r=-0,477)$; hubungan negatif yang signifikan pada kelompok $2(p=0,04, r=-0,817)$; dan hubungan positif yang tidak signifikan pada kelompok $3(p=0,518, r=0,232)$. Hasil uji Kruskal-Wallis menunjukkan perbedaan yang tidak signifikan $(p>0,05)$ rerata kadar ROS pada kelompok gradasi katarak II, III, dan IV. HbA1C dapat digunakan sebagai salah satu penanda peningkatan ROS pada pasien katarak diabetika, dimana tingginya kadar ROS diperkirakan akan menyebabkan peningkatan progresifitas katarak.
\end{abstract}

Kata kunci: diabetes melitus, gradasi katarak, HbA1C, katarak, ROS.

\section{CORRELATION BETWEEN HBA1C LEVEL WITH REACTIVE OXYGEN SPECIES IN THE BLOOD SERUM AND CATARACT GRADING IN CATARACT PATIENTS WITH DIABETES MELLITUS}

\begin{abstract}
Cataract is a disorder characterized by opacification of the lens of eyes. Cataract can cause by the aging process or diabetes mellitus. Hyperglycemia is associated with oxidative stress which plays roles in cataract formation. This study aims to determine the relationship between $\mathrm{HbA1C}$ levels and reactive oxygen species (ROS) in cataract patients with type 2 diabetes mellitus. This is an observational study with a crosssectional design. It involved 44 subjects selected with consecutive sampling technique and divided into four groups based on HbA1C levels: (1). normal HbA1C, (2). well-controlled HbA1C $(<6.5 \%)$, (3). moderately controlled $\mathrm{HbA} 1 \mathrm{C}(6.5-7.9 \%)$, and (4). poorly controlled $\mathrm{HbA1C}(\geq 8 \%)$; and three groups based on cataract grade. The Kruskal-Wallis test results showed a significant difference $(p<0.05)$ of ROS mean levels in each HbA1C group. Then, based on the Mann-Whitney test, it revealed significant differences between group 1 with groups 2, 3, and 4; and group 2 with 3 and 4; and no significant differences between groups 3 and 4 . The Spearman correlation test results showed that there was a non-significant negative relationship between HbA1C levels and ROS in group $1(p=0.958, r=-0.016)$ and in group $4(p=0.163, r=-0.477)$; a significant negative relationship in group 2 ( $p=0.04, r=-0.817)$; and a non-significant positive relationship in group 3 ( $p$ $=0.518, r=0.232)$. The Kruskal-Wallis test results showed no significant differences $(p>0.05)$ of the ROS mean levels in the cataract groups grade II, III, and IV. HbA1C levels can be used as a marker of ROS increment in cataract patients with diabetes mellitus type 2 , where high rates of ROS are predicted to cause the cataract progression.
\end{abstract}

Keywords: cataract, cataract grading, HbA1C, ROS, type-2 diabetes mellitus.

${ }^{*}$ Departemen Ilmu Kesehatan Mata, Fakultas Kedokteran, Universitas Brawijaya-RSUD Dr. Saiful Anwar. Malang ${ }^{* *}$ Program Studi Sariana (S1) Kedokteran, Fakultas Kedokteran, Universitas Brawijaya

E-mail: ninahdyn@gmail.com 


\section{Pendahuluan}

Diabetes melitus merupakan suatu penyakit metabolik kronis yang menjadi satu dari empat prioritas penyakit tidak menular $\mathrm{di}$ dunia. Prevalensi dan mortalitas diabetes melitus yang tinggi masih menjadi masalah kesehatan serius baik di negara maju maupun negara berkembang. Menurut WHO, pada tahun 2014 dilaporkan 422 juta penderita diabetes melitus, dan pada tahun 2016 dilaporkan 1,6 juta kematian akibat penyakit ini. ${ }^{1}$

Secara epidemiologi, pada tahun 2017 prevalensi diabetes melitus di Indonesia menduduki peringkat keenam dunia menyusuli Cina, India, Amerika Serikat, Brazil, dan Meksiko dengan jumlah estimasi 10,3 juta orang. ${ }^{2}$ Di Indonesia, sebanyak dua per tiga penderita diabetes melitus tidak menyadari akan penyakitnya, sehingga berpeluang terlambat untuk mengakses layanan kesehatan, yakni sudah dengan komplikasi. Diabetes melitus disertai komplikasi merupakan penyumbang kematian tertinggi nomor tiga di Indonesia. ${ }^{3}$

Katarak merupakan suatu kelainan yang ditandai dengan adanya kekeruhan pada lensa mata, sehingga mengurangi jumlah cahaya yang masuk dan mengakibatkan berkurangnya penglihatan. Mekanisme pembentukan katarak sangat multifaktorial. Selain karena proses penuaan, faktor lain yang dapat terlibat dalam proses pembentukan katarak antara lain herediter, trauma, toksik, radiasi, elektrik, dan metabolik, termasuk diabetes melitus. ${ }^{4}$ Pada studi yang dilakukan oleh Wisconsin Epidemiologic Study risiko terjadinya katarak meningkat 2-5 kali pada pasien diabetes dibandingkan dengan pasien nondiabetes. ${ }^{5}$ Studi dari Framingham Eye Study juga mengungkapkan bahwa pasien diabetes melitus di bawah 65 tahun berisiko 3-4 kali menderita katarak dan 2 kali lebih berisiko pada usia di atas 65 tahun dibandingkan dengan pasien nondiabetes. ${ }^{6}$

Menurut Depkes (2010), dari total prevalensi kebutaan sebesar 1,5\%, katarak merupakan penyumbang utama kebutaan di Indonesia dengan prevalensi $0,78 \%$. Data dari Biro Pusat Statistik (BPS) menunjukkan 16-20\% buta katarak dialami oleh penduduk Indonesia usia produktif 40-54 tahun. ${ }^{7}$ Selain faktor usia, faktor risiko utama kejadian katarak di atas usia 30 tahun di Indonesia antara lain diabetes melitus. ${ }^{[8]}$

Kondisi hiperglikemia pada pasien diabetes melitus berhubungan dengan proses stres osmotik, glikasi nonenzimatik, dan stres oksidatif yang berperan dalam pembentukan katarak. ${ }^{4}$ Stres osmotik pada pasien diabetes melitus terjadi sebagai akibat dari peningkatan jalur polyol. Peningkatan jalur polyol menyebabkan akumulasi sorbitol yang dapat memicu terjadinya stres pada retikulum endoplasma yang berdampak pada pembentukan ROS (reactive oxygen species) dan menyebabkan kerusakan stres oksidatif pada serat lensa. Selain itu, proses glikasi nonenzimatik berakibat pada pembentukan AGE (advanced glycation endproducts) yang juga dapat menyebabkan kerusakan pada serat lensa. ${ }^{9}$

Hemoglobin terglikasi ( $\mathrm{HbA} 1 \mathrm{C})$ merupakan salah satu parameter yang dapat menilai fluktuasi glukosa dalam darah, sehingga dapat digunakan sebagai kontrol dan monitoring jangka panjang pada pasien diabetes. HbA1C menggambarkan glukosa darah 2-3 bulan sebelumnya dan dapat digunakan sebagai pertimbangan dan penilaian pasien diabetes terhadap risiko komplikasi yang akan terjadi. ${ }^{10}$

Salah satu spektrum penyakit mata yang terjadi sebagai komplikasi kondisi hiperglikemia kronis adalah katarak. Berdasarkan tingkat kekeruhannya, katarak dibedakan menjadi 5 gradasi dengan semakin tinggi gradasi akan menunjukkan bahwa kekeruhan pada lensa semakin tebal. 
Penelitian tentang katarak diabetika yang mengkaji patomekanisme katarak pada pasien diabetes masih sangat terbatas, sehingga perlu dilakukan penelitian lebih lanjut tentang patogenesis katarak pada pasien diabetes. Penelitian ini berusaha mempelajari peranan variabel biokimia dalam perkembangan katarak diabetika, yaitu bertujuan untuk mengetahui hubungan antara tinggi kadar $\mathrm{HbA1C}$ dengan ROS dalam serum darah pasien katarak diabetika.

\section{Bahan dan Metode}

Penelitian ini bersifat observasional analitik dengan rancangan cross-sectional. Sampel diperoleh secara konsekutif yakni pasien dengan rentang usia 50-79 tahun yang berobat atau kontrol ke Poli Mata RSUD dr. Saiful Anwar Malang Subdivisi Katarak dan Bedah Refraktif dengan diagnosis katarak disertai diagnosis diabetes melitus tipe 2 oleh Poli Endokrin IImu Penyakit Dalam RSUD dr. Saiful Anwar Malang yang telah memenuhi kriteria inklusi dan eksklusi. Kriteria inklusi pada penelitian ini meliputi pasien dengan diagnosis katarak, berusia 50-79 tahun, terdiagnosis DM tipe-2 oleh Poli Endokrin IImu Penyakit Dalam RSUD dr. Saiful Anwar Malang, setuju mengikuti penelitian dan menandatangani lembar persetujuan. Sementara kriteria eksklusi pada penelitian ini meliputi pasien dengan diagnosis katarak traumatika, terdapat kekeruhan pada kornea mata, adanya infeksi akut, inflamasi kronis (inflammatory bowel disease, osteoarthritis, rheumatoid arthritis, hepatitis kronis, gout, dan asma brochiale), penyakit kardiovaskular (angina pectoris, infark miokard akut, infark cerebri), dan riwayat keganasan. Anamnesa, pemeriksaan fisik, dan pemeriksaan status oftalmologi dilakukan pada 44 subjek penelitian yang sesuai dengan kriteria inklusi. Penelitian ini telah dinyatakan laik etik oleh Komisi Etik Penelitian Kesehatan RSUD Dr. Saiful Anwar dengan nomor: 400/128/

\section{K.3/302/2017.}

Pemeriksaan gradasi katarak dilakukan dengan pemeriksaan slit lamp biomikroskopi berdasarkan klasifikasi Burratto. Subjek penelitian kemudian dibagi menjadi 3 kelompok berdasarkan gradasi kataraknya: gradasi II, gradasi III, dan gradasi IV. Kemudian diambil sebanyak 2, $5 \mathrm{ml}$ sampel darah puasa vena dari subjek untuk diperiksa kadar $\mathrm{HbA} 1 \mathrm{C}$ dan ROS. Berdasarkan kadar $\mathrm{HbA1C}$, subjek kemudian dibagi menjadi 4 kelompok: (1). HbA1C normal, (2). HbA1C terkontrol baik $(<6,5 \%), \quad(3) . \quad \mathrm{HbA} 1 \mathrm{C}$ terkontrol sedang $(6,5-7,9 \%)$, dan (4). $\mathrm{HbA} 1 \mathrm{C}$ terkontrol buruk $(\geq 8 \%)$.

Pengukuran kadar ROS dalam serum menggunakan Human ROS ELISA Kit dan dilakukan dengan metode Sandwich-ELISA. Prosedurnya, sampel sebanyak $40 \mu \mathrm{L}$ dan 10 $\mu \mathrm{L}$ biotinylated human anti-ROS antibody ditambahkan pada setiap micro ELISA plate well sampel. Kemudian pada micro ELISA plate well sampel dan standar, ditambahkan $50 \mu \mathrm{L}$ streptavidin-HRP conjugate, dicampur, dan ditutup dengan sealer, dan diinkubasikan pada suhu $37^{\circ} \mathrm{C}$ selama 1 jam. Setelah itu, dilakukan pencucian dengan wash buffer sebanyak 5 kali. Prosedur berikutnya adalah menambahkan $50 \mu \mathrm{L}$ substrate solution A dan $50 \mu \mathrm{L}$ substrate solution B pada masingmasing sumur, ditutup dengan sealer, dan diinkubasikan kembali pada suhu 37 o selama 10 menit pada ruang gelap. Selanjutnya, ditambahkan $50 \mu \mathrm{L}$ stop solution dan dilakukan pengukuran optical density dengan panjang gelombang $450 \mathrm{~nm}$ microplate reader. Hasil absorbansi yang diperoleh selanjutnya dibuat kurva standar dengan menggunakan aplikasi Ms. Excel, sehingga diperoleh suatu persamaan matematis. Penentuan kadar ROS ( $x$ ) dilakukan dengan memasukkan $\mathrm{y}=\mathrm{OD}$ pada persamaan yang telah diperoleh dari kurva standar. 
Penentuan kadar ROS $(\mathrm{x})$ dilakukan dengan memasukkan $\mathrm{y}=\mathrm{OD}$ pada persamaan yang telah diperoleh dari kurva standar. Pengukuran HbA1C dilakukan dengan metode kromatografi afinitas (HPLC) dengan alat Bio Rad D10'M di Laboratorium Sentral Patologi Klinik RSUD Dr. Saiful Anwar Malang. Analisis data menggunakan program SPSS 15 for Windows. Untuk mengetahui perbedaan rerata kadar ROS serum antar kelompok digunakan uji One Way ANOVA, dilanjutkan dengan uji pembandingan berganda uji Tukey, atau dengan uji KruskalWallis dan dilanjutkan dengan uji Mann Whitney jika asumsi data tidak terpenuhi. Sedangkan untuk mengetahui hubungan antara variabel $\mathrm{HbA} 1 \mathrm{C}$ dan ROS digunakan uji korelasi Pearson atau uji Spearman jika asumsi data tidak terpenuhi.

\section{Hasil}

Karakteristik Subjek Penelitian

Selama penelitian didapatkan subjek sebanyak 44 pasien yang memenuhi kriteria inklusi dan eksklusi. Berdasarkan jenis kelamin, didapatkan 24 pasien berjenis kelamin laki-laki $(54,54 \%)$ dan 20 pasien berjenis kelamin perempuan $(45,46 \%)$ (Tabel 1). Berdasarkan kadar $\mathrm{HbA1C}$, didapatkan 14 pasien kelompok $\mathrm{HbA1C}$ kontrol normal, 10 pasien kelompok $\mathrm{HbA} 1 \mathrm{C}$ terkontrol baik $(<6,5 \%), 10$ pasien kelompok $\mathrm{HbA1C}$ terkontrol sedang (6, 5-7, 9\%), dan 10 pasien kelompok $\mathrm{HbA1C}$ terkontrol buruk $(\geq 8 \%) \quad$ (Tabel 2). Sementara itu, berdasarkan gradasi kataraknya, didapatkan 14 pasien kelompok gradasi II, 17 pasien kelompok gradasi III, dan 13 pasien kelompok gradasi IV (Tabel3).

Tabel 1. Karakteristik subjek berdasarkan jenis kelamin

\begin{tabular}{lccc}
\hline \multicolumn{2}{c}{ Karakteristik } & Jumlah & Persentase \\
\hline \multirow{2}{*}{ Jenis Kelamin } & Laki-laki & 24 & $54,54 \%$ \\
& Perempuan & 20 & $45,46 \%$ \\
Total & & 44 & $100 \%$ \\
\hline
\end{tabular}

Tabel 2. Karakteristik subjek berdasarkan kadar $\mathrm{HbA1C}$

\begin{tabular}{|c|c|c|}
\hline Kadar $\mathrm{HbA} 1 \mathrm{C}$ & Frekuensi & Persentase \\
\hline (Kelompok 1) & 14 & $31,81 \%$ \\
\hline $\mathrm{HbA} 1 \mathrm{C}$ terkontrol baik $(<6,5 \%)$ (kelompok 2$)$ & 10 & $22,73 \%$ \\
\hline $\mathrm{HbA1C}$ terkontrol sedang $(6,5-7,9 \%)$ (kelompok 3$)$ & 10 & $22,73 \%$ \\
\hline $\mathrm{HbA} 1 \mathrm{C}$ terkontrol buruk $(\geq 8 \%$ ) (kelompok 4$)$ & 10 & $22,73 \%$ \\
\hline
\end{tabular}

Tabel 3. Karakteristik subjek berdasarkan gradasi katarak

\begin{tabular}{ccr}
\hline Gradasi Katarak & Frekuensi & Persentase \\
\hline II & 14 & $31,81 \%$ \\
III & 17 & $38,63 \%$ \\
IV & 13 & $29,54 \%$ \\
\hline
\end{tabular}


Rerata Kadar ROS pada Kelompok HbA1C

Rerata kadar ROS serum pada seluruh kelompok HbA1C sebesar 1454,07士1210,69 U/L. Rerata kadar ROS tertinggi adalah pada kelompok $2 \quad \mathrm{HbA} 1 \mathrm{C}$ sebesar $2046,38 \pm 1545,99 \mathrm{U} / \mathrm{L}$, sedangkan rerata kadar ROS terendah adalah pada kelompok 3 HbA1C sebesar 1117,25 \pm 940,53 U/L (Tabel 4). Hasil uji normalitas dengan KolmogorovSmirnov menunjukkan distribusi rerata kadar ROS tidak normal. Hasil uji homogenitas ragam data dengan Levene juga menunjukkan ragam data tidak homogen. Hasil analisis uji beda dengan Kruskal Wallis menunjukkan adanya perbedaan signifikan rerata kadar ROS pada masing-masing kelompok HbA1C ( $p=0,011)$. Hasil analisis lanjutan perbedaan antar kelompok dengan uji Mann Whitney tidak didapatkan adanya perbedaan yang signifikan antara kelompok 1 dengan kelompok 2, 3, dan 4; terdapat perbedaan signifikan antara kelompok 2 dengan 3 dan 4; dan tidak didapatkan adanya perbedaan yang signifikan antara kelompok 3 dan 4.

Hubungan antara Seluruh Kelompok HbA1C Dibandingkan dengan Kadar ROS

Hasil uji korelasi Spearman menunjukkan adanya hubungan negatif yaitu semakin tinggi kadar $\mathrm{HbA} 1 \mathrm{C}$ semakin rendah kadar ROS yang didapatkan. Hubungan ini menunjukkan hasil tidak signifikan $(p=$ 0, 052) antara kadar HbA1C dengan ROS, dengan koefisien korelasi sebesar 0,294. Hubungan antara kadar $\mathrm{HbA} 1 \mathrm{C}$ dengan ROS ditunjukkan pada Gambar 2.

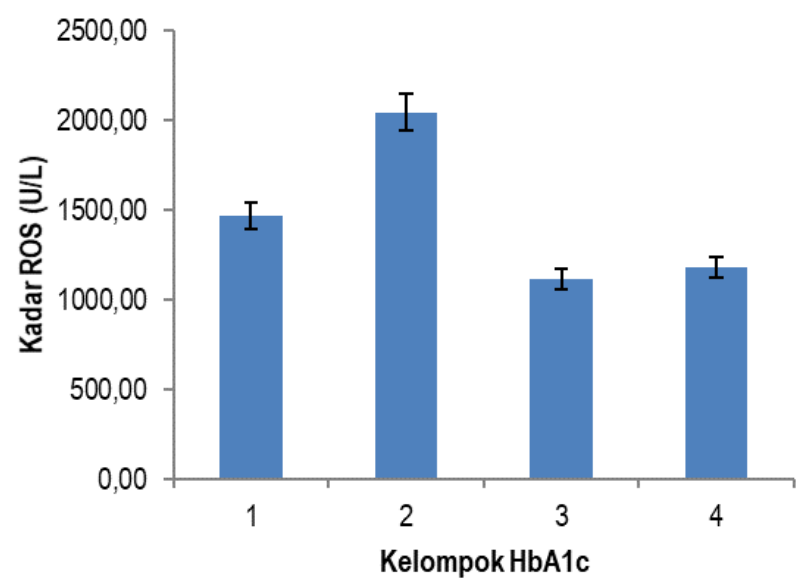

Gambar 1. Rerata kadar ROS pada masing-masing kelompok HbA1C.

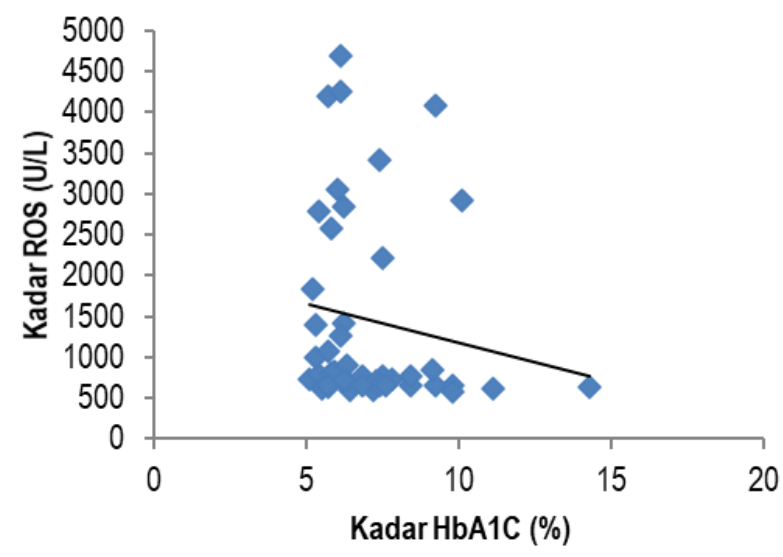

Gambar 2. Hubungan kadar HbA1C dengan ROS pada seluruh kelompok HbA1C. 
Hubungan antara Kelompok $1 \mathrm{HbA1C}$ Dibandingkan dengan Kadar ROS

Hasil uji korelasi Spearman menunjukkan adanya hubungan negatif atau berbalik arah yang tidak signifikan $(p=0,958)$ antara kadar $\mathrm{HbA1C}$ dengan ROS pada kelompok $1 \mathrm{HbA1C}$, dengan koefisien korelasi sebesar 0,016. Hubungan antara kadar $\mathrm{HbA} 1 \mathrm{C}$ dengan ROS pada kelompok 1 HbA1C ditunjukkan pada Gambar 3.

Hubungan antara Kelompok 2 HbA1C Dibandingkan dengan Kadar ROS

Hasil uji korelasi Spearman menunjukkan adanya hubungan negatif atau berbalik arah yang signifikan $(p=0,004)$ antara kadar $\mathrm{HbA} 1 \mathrm{C}$ dengan ROS pada kelompok $2 \mathrm{HbA} 1 \mathrm{C}$, dengan koefisien korelasi sebesar 0,817, angka ini menunjukkan adanya korelasi tinggi karena termasuk dalam rentang 0,80-1,00. Hubungan antara kadar $\mathrm{HbA} 1 \mathrm{C}$ dengan ROS pada kelompok $2 \mathrm{HbA} 1 \mathrm{C}$ ditunjukkan pada Gambar 4.

Hubungan antara Kelompok 3 HbA1C Dibandingkan dengan Kadar ROS

Hasil uji korelasi Spearman menunjukkan adanya hubungan positif atau searah, yaitu semakin tinggi kadar $\mathrm{HbA} 1 \mathrm{C}$ maka semakin tinggi juga kada ROS, namun hasilnya tidak signifikan $(p=0,518)$, dengan koefisien korelasi sebesar 0,232 . Hubungan antara kadar $\mathrm{HbA1C}$ dengan ROS pada kelompok $3 \mathrm{HbA} 1 \mathrm{C}$ ditunjukkan pada Gambar 5 .

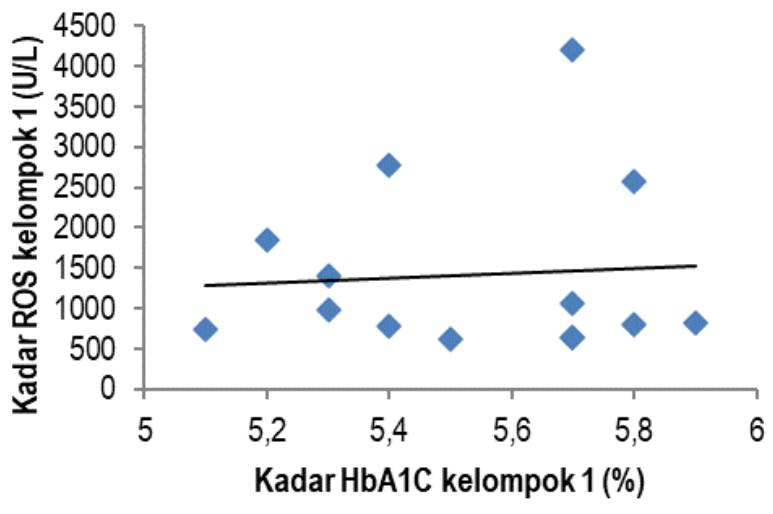

Gambar 3. Hubungan kadar HbA1C dengan ROS pada kelompok $1 \mathrm{HbA} 1 \mathrm{C}$.

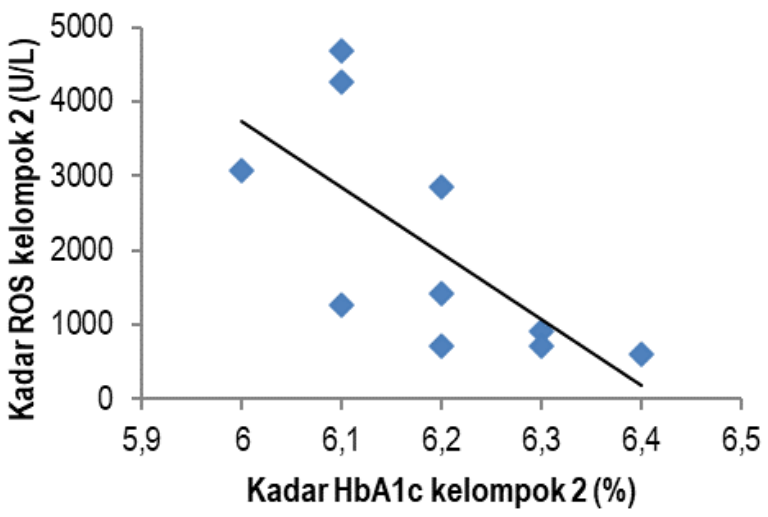

Gambar 4. Hubungan kadar HbA1C dengan ROS pada kelompok $2 \mathrm{HbA1C}$. 
Hubungan antara Kelompok 4 HbA1C Dibandingkan dengan Kadar ROS

Hasil uji korelasi Spearman menunjukkan adanya hubungan negatif atau berbalik arah yang tidak signifikan $(p=0,163)$ antara kadar $\mathrm{HbA1C}$ dengan ROS pada kelompok $4 \mathrm{HbA} 1 \mathrm{C}$, dengan koefisien korelasi sebesar 0,477. Hubungan antara kadar $\mathrm{HbA1C}$ dengan ROS pada kelompok $4 \mathrm{HbA1C}$ ditunjukkan pada Gambar 6.

Perbedaan Rerata ROS antar Kelompok Gradasi Katarak

Rerata kadar ROS pada kelompok gradasi katarak II, III, dan IV masing-masing sebesar 1294,75 \pm 907,12 U/L, 1468,42 \pm 1279,26 U/L, dan 1606,87 $\pm 1457,29 \mathrm{U} / \mathrm{L}$. Dengan demikian, rerata kadar ROS terendah pada kelompok gradasi katarak II, sedangkan tertinggi pada kelompok gradasi katarak IV (Gambar 7). Hasil uji normalitas dengan Shapiro Wilk menunjukkan distribusi data tidak normal. Hasil uji homogenitas ragam data dengan Levene menunjukkan ragam data homogen. Hasil analisis uji beda dengan Kruskal Wallis menunjukkan adanya perbedaan yang tidak signifikan rerata kadar ROS pada ketiga kelompok gradasi katarak ( $\mathrm{p}$ $=0,938$ ).

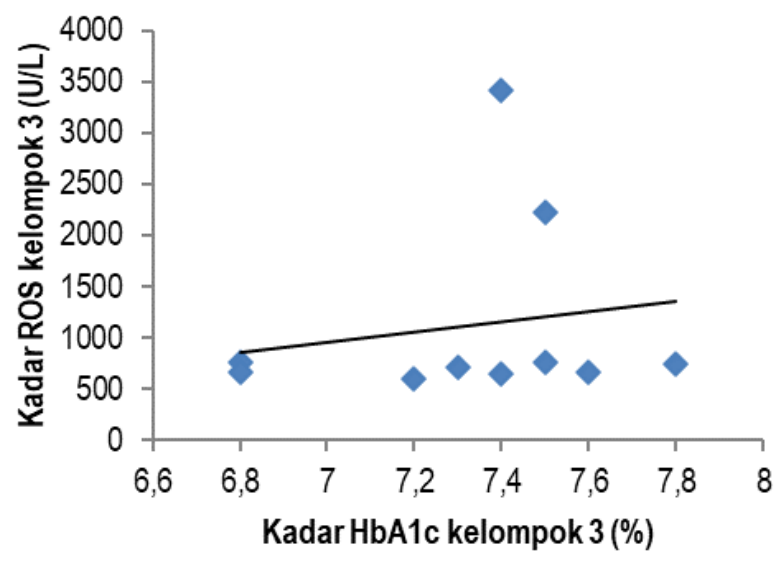

Gambar 5. Hubungan kadar HbA1C dengan ROS pada kelompok $3 \mathrm{HbA1C}$.

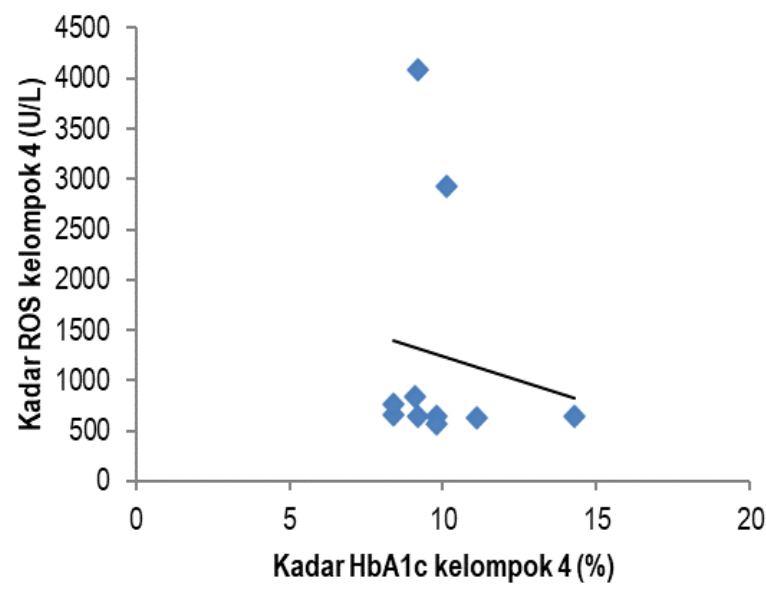

Gambar 6. Hubungan kadar HbA1C dengan ROS pada kelompok $4 \mathrm{HbA} 1 \mathrm{C}$. 


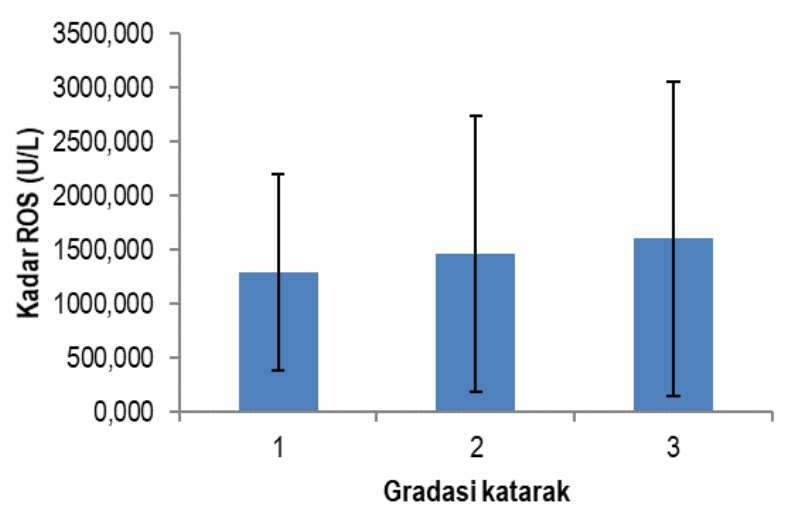

Gambar 7. Rerata kadar ROS pada masing-masing kelompok gradasi katarak.

\section{Pembahasan}

Pada penelitian ini didapatkan 44 subjek penelitian yang memenuhi kriteria inklusi dengan distribusi jenis kelamin sebesar 20 orang $(45,46 \%)$ berjenis kelamin perempuan dan 24 orang $(54,54 \%)$ berjenis kelamin lakilaki. Secara statistik, tidak didapatkan perbedaan jenis kelamin dalam prevalensi katarak dan diabetes melitus tipe-2. Hal ini sesuai dengan teori dari Lathika dan Ajith (2016), dalam sebuah penelitian yang diterbitkan di India ditemukan kejadian katarak pada kedua jenis kelamin pasien diabetes melitus tipe-2 tidak mempunyai perbedaan yang besar antara laki-laki dan perempuan. ${ }^{13}$

Pada penelitian ini, didapatkan hasil pengukuran rerata kadar ROS pada kelompok kontrol (kelompok $1 \mathrm{HbA1C}$ ) sebesar 1422,96 U/L. Nilai rerata kadar ROS pada kelompok diabetes sebesar 1468,58 U/L dengan rincian antara lain sebesar: $2046,38 \pm 1545,99 \mathrm{U} / \mathrm{L}$ pada kelompok $2 \mathrm{HbA1C}, 1117,25 \pm 940,53 \mathrm{U} /$ $\mathrm{L}$ pada kelompok $3 \mathrm{HbA} 1 \mathrm{C}$, dan 1242,13 U/L pada kelompok $4 \mathrm{HbA} 1 \mathrm{C}$. Didapatkan juga rerata kadar ROS seluruh kelompok $\mathrm{HbA1C}$ sebesar 1454,068 $\pm 1226,02 \quad \mathrm{U} / \mathrm{L}$, dengan rerata tertinggi pada kelompok 2 dan terendah pada kelompok 3. Hasil uji Kruskal Wallis menunjukkan adanya perbedaan signifikan kadar ROS antar kelompok HbA1C ( $p=$ 0,011) dan hasil uji Mann Whitney menunjukkan adanya perbedaan signifikan antara kelompok 2 dengan kelompok 3 dan 4 , perbedaan yang tidak signifikan antara kelompok 3 dan 4, dan perbedaan yang tidak signifikan antara kelompok kontrol dengan ketiga kelompok diabetes lainnya. Meskipun demikian, dengan melihat data yang didapatkan, rerata kadar ROS pada kelompok diabetes lebih tinggi daripada kelompok kontrol. Hal ini dikarenakan pada kondisi hiperglikemia kronis terjadi peningkatan reaksi stres oksidatif. Kondisi stres oksidatif menyebabkan terjadinya peningkatan produksi ROS mitokondria pada sel endotel pembuluh darah besar maupun kecil. Kelebihan ROS akan mengaktifkan 5 jalur yang berperan dalam patogenesis komplikasi diabetes yakni polyol pathway flux, peningkatan pembentukan AGEs, peningkatan ekspresi reseptor AGEs, aktivasi PKC, dan aktivitas berlebihan pada jalur hexoxamine. 14,15

Tidak adanya perbedaan kadar ROS yang signifikan antara kelompok kontrol dan kelompok diabetes mellitus diduga karena adanya suatu mekanisme adaptasi alami sel tubuh dalam merespons kondisi stres oksidatif kronis.

Hal ini didukung dengan penelitian oleh Chandrasena et al. (2006) yang menyatakan bahwa terdapat respons peningkatan antioksidan yang melindungi tubuh dari kerusakan akibat kondisi stres oksidatif kronis, yaitu terdapat peningkatan aktivitas enzim anti oksidan antara lain: katalase, glutathione peroxidase (GPX), dan superoxide dismutase (SOD) pada pasien katarak dengan diabetes dibandingkan pasien katarak tanpa diabetes. ${ }^{16}$ 
Ketiga enzim tersebut disebut juga scavenger enzyme, yakni enzim yang bertugas menangkap ROS. Penelitian oleh Yildirim et al. (2009) menunjukkan bahwa kadar malondialdehyde (MDA), glutathion (GSH), advanced oxidation protein products (AOPP), dan aktivitas SOD meningkat pada katarak senilis dengan diabetes dibandingkan katarak senilis tanpa diabetes. ${ }^{17}$

Hasil uji korelasi kadar $\mathrm{HbA} 1 \mathrm{C}$ dengan ROS pada setiap kelompok $\mathrm{HbA1C}$ menunjukkan bahwa hanya pada kelompok 3 didapatkan adanya kecenderungan peningkatan kadar ROS terhadap peningkatan kadar $\mathrm{HbA} 1 \mathrm{C}$, walaupun belum bermakna secara statistik. Adanya kondisi hiperglikemia kronis mengakibatkan aktivasi jalur polyol, glikasi nonenzimatik, dan autooksidasi glukosa yang berperan dalam pembentukan senyawa oksigen reaktif. Pada kondisi hiperglikemia, jalur glikolisis anaerobik menjadi cepat jenuh, sehingga glukosa akan masuk ke jalur polyol yang akan diubah menjadi sorbitol oleh enzim aldosa reduktase, berakhir pada penumpukan sorbitol intrasel, sehingga terjadi stres osmotik yang akan menginduksi stres di RE yang merupakan tempat utama sintesis protein dan menyebabkan terbentuknya radikal bebas. ${ }^{18}$ Stres RE juga dapat disebabkan oleh adanya kadar glukosa yang berfluktuasi dan menginisasi unfolded protein response (UPR) yang akan membentuk ROS dan menyebabkan kerusakan pada serabut lensa karena stres oksidatif. ${ }^{19}$ Selain itu, juga terjadi reaksi glikasi nonenzimatik yang pada akhirnya menghasilkan AGEs, yang jika menumpuk dapat menjadi sumber utama radikal bebas sehingga mampu berperan dalam peningkatan stres oksidatif. ${ }^{20}$

Adanya korelasi negatif tinggi pada kelompok 2 dan korelasi negatif yang kembali didapatkan pada kelompok $4 \mathrm{HbA} 1 \mathrm{C}$ diduga karena adanya suatu mekanisme kompensasi tubuh dari kerusakan akibat stres oksidatif. Kondisi ini didukung oleh Tavares et al., yang melakukan studi observasi mengenai marker stres oksidatif terhadap pasien DM tipe 2 (T2DM) yang terbagi menjadi kelompok kontrol, prediabetes, T2DM subgrup $A$ ( $\mathrm{HbA} 1 \mathrm{C}<7 \%)$, subgrup $\mathrm{B}(\mathrm{HbA} 1 \mathrm{C} 7-9 \%)$, dan subgrup $\mathrm{C}(\mathrm{HbA} 1 \mathrm{C}>9 \%)$. Pada penelitian tersebut, didapatkan korelasi positif antara aktivitas SOD dengan level $\mathrm{HbA} 1 \mathrm{C}$, dengan aktivitas SOD plasma tertinggi berada pada kelompok pasien T2DM dibandingkan dengan kontrol. Lebih lanjut lagi, dijelaskan bahwa kecenderungan peningkatan aktivitas SOD tertinggi pada grup A $(2,18[1,97-3,34])$, menurun pada grup $B(2,18[1,97-3,34])$, dan kembali meningkat pada grup $C(2,38$ $[1,97-3,74])$. Hasil serupa juga dijumpai pada parameter aktivitas GPx, sejalan dengan penelitian ini yang menunjukkan adanya peningkatan aktivitas GPx tertinggi pada grup $A$, menurun pada grup $B$, dan kembali meningkat pada grup $C .{ }^{21}$

Hasil uji beda rerata ROS antar gradasi katarak menunjukkan adanya kecendrungan kadar ROS yang semakin tinggi terhadap penambahan gradasi katarak, namun belum bermakna secara statistik dalam mendukung teori peranan stres oksidatif dalam progresifitas katarak melalui pengukuran biomarker ROS. Beberapa publikasi terakhir melaporkan peranan antioksidan dan produk akhir aktivitas ROS dalam memprediksi stres oksidatif pada pasien katarak. Studi oleh Putra (2014) menemukan adanya korelasi negatif kuat antara kadar SOD dengan derajat kekeruhan lensa ( $p=0,001, r=$ $0,9) .{ }^{22}$ Penelitian oleh Sulistya et al. (2006), menemukan perbedaan signifikan $(p=0,00)$ kadar glutation reduktase berdasarkan derajat kekeruhan inti lensa, yaitu didapatkan kadar glutation reduktase yang rendah pada derajat katarak yang paling tinggi, dan sebaliknya. ${ }^{23}$ 
Kedua penelitian ini menunjang teori peranan stres oksidatif dalam progresifitas katarak, yakni melalui pengukuran biomarker SOD dan glutation reduktase. Hasil yang tidak signifikan pada penelitian ini diduga akibat pengaruh faktor jumlah sampel yang masih sangat terbatas. Walaupun tidak terdapat perbedaan yang signifikan rerata kadar ROS antar kelompok gradasi katarak, namun kemungkinan gangguan pada metabolisme oksidatif dan peranannya dalam progresifitas katarak belum dapat dieliminasi.

\section{Kesimpulan}

Terdapat hubungan yang signifikan dan searah antara kadar $\mathrm{HbA} 1 \mathrm{C}$ dengan ROS pada kelompok $\mathrm{HbA1C}$ yang terkontrol sedang. Terdapat perbedaan yang signifikan kadar ROS dalam serum darah pasien antara kelompok $\mathrm{HbA} 1 \mathrm{C}$ yang terkontrol baik dibandingkan kelompok $\mathrm{HbA} 1 \mathrm{C}$ yang terkontrol sedang dan buruk. Terdapat perbedaan tidak signifikan antara kadar ROS dengan semua kelompok gradasi katarak.

\section{Daftar Pustaka}

1. World Health Organization. Global Report on Diabetes. France: World Health Organization. 2016. HIm. 22-25.

2. International Diabetes Federation. IDF Diabetes Atlas Eighth Edition 2017. International Diabetes Federation. 2017. HIm. 46.

3. World Health Organization. Diabetes Fakta dan Angka. (Online). 2015. http:// www.searo.who.int/indonesia/topics/8whd2016diabetesfactsandnumbersindonesian.pdf. Diakses 8 Desember 2018.

4. Gupta V, Rajagopala M, Ravishankar B. Etiopathogenesis of Cataract: An Appraisal. Indian Journal of Ophthalmology. 2014; 62(2):103-10.
5. Klein BEK, Klein R, Moss SE. Incidence of Cataract Surgery in the Wisconsin Epidemiologic Study of Diabetic Retinopathy. Am J Ophthalmol. 1995; 119 (3):295-300.

6. Klein BEK, Klein R, Moss SE. Prevalence of Cataracts in a Population-based Study of Persons with Diabetes Mellitus. Ophthalmology. 1985; 92(9):1191-6.

7. Departemen Kesehatan Republik Indonesia. Gangguan Penglihatan Maasih Menjadi Masalah Kesehatan. (Online). 2010. http://www.depkes.go.id/article/ view/845/gangguan-penlihatan-masihmenjadi-masalah-kesehatan.html. Diakses 8 Desember 2018.

8. Tana L. Cataract Surgical Coverage Rate among Adults Aged 40 Years and Above. Univ Med. 2009; 28(3):161-9.

9. Pollreisz A., Erfurth U.S. Diabetic Cataract-Pathogenesis, Epidemiology and Treatment. J Ophthalmol. 2010; 2010: 608751. doi: 10.1155/2010/608751.

10.Lindfield R, Vishwanath K, Ngounou F, Khanna RC. The Challenges in Improving Outcome of Cataract Surgery in Low and Middle Income Countries. Indian J Ophthalmol. 2012; 60(5):464-9.

11. Kemenkes RI. Situasi Gangguan Penglihatan dan Kebutaan: Info Datin. Jakarta: Pusat Data Informasi Kementerian Kesehatan RI. 2010. HIm. 3 dan 9.

12.Javadi MA, Ghanavati SZ. Cataracts in Diabetic Patients: A Review Article. J Ophthalmic Vis Res. 2008; 3(1):52-65.

13. Lathika V, Ajith T. Association of Grade of Cataract with Duration of Diabetes, Age and Gender in Patients with Type II Diabetes Mellitus. Int J Adv Med. 2016; 3 (2):304-8.

14. Giacco F, Brownlee M. Oxidative Stress and Diabetic Complications. Circulation Research. 2010; 107:1058-70. 
15. Wu Y, Tang L, Chen B. Oxidative Stress: Implications for The Development of Diabetic Retinopathy and Antioxidant Therapeutic Perspectives. Oxid Med Cell Longev. 2014; 2014(3).

16. Chandrasena LG, Chackrewarthy S, Perera PTMJ, De Silva D. Brief Communication: Erythrocyte Antioxidant Enzymes in Patients with Cataract. Ann Clin Lab Sci. 2006; 36(2):201-4.

17. Yildirim Z, Yildirim F, Ucgun NI, Kilic N. The Evaluation of The Oxidative Stress Parameters in Nondiabetic and Diabetic Senile Cataract Patients. Biol Trace Elem Res. 2009; 128(2):135-43.

18. Hulke SM, Dhone PG, Vaidya PV, Gupta SB. Pathogenesis of Diabetic Cataract. Acta Biomedica Scientia. 2017; 4(1):2834.

19. Mulhern ML, Madson CJ, Danford A, Ikesugi K, Kador PF, Shinohara T. The Unfolded Protein Response in Lens Epithelial Cells from Galactosemic Rat Lenses. Investig Ophthalmol Vis Sci. 2006; 47(9):3951-59.
20. Hong SB, Lee KW, Handa JT, Joo CK. Effect of Advanced Glycation End Products on Lens Epithelial Cells in Vitro. Biochem Biophys Res Commun. 2000; 275(1):53-9.

21. Tavares AM, Silva JH, de Oliveira Bensusan C, Ferreira ACF, de Lima Matos LP, de Araujo e Souza KL, et al. Altered Superoxide Dismutase-1 Activity and Intercellular Adhesion Molecule 1 (ICAM-1) Levels in Patients with Type 2 Diabetes Mellitus. PLoS One. 2019; 14 (5):1-10.

22. Putra IPR. Penurunan Kadar Superoksida Dismutase Lensa Berhubungan dengan Peningkatan Derajat Kekeruhan Lensa pada Katarak Senilis. Tesis. Tidak Diterbitkan. Denpasar. Program Pascasarjana Fakultas Kedokteran Universitas Udayana. 2014.

23. Sulistya TB, Dewi DS, Sujuti $H$, Sumarno. Hubungan antara Kadar Enzim Glutation Reduktase dengan Derajat Kekeruhan Inti Lensa. Jurnal Kedokteran Brawijaya. 2006; 22(1):40-6. 